\title{
The role of the primary care outpatient clinic in the promotion of healthy nutrition - preliminary reports
}

MARTA DUDZIŃSKA ${ }^{1, \text { A-F }}$ MONIKA NEĆ2, A-F AGNIESZKA ZWOLAK 1, 2, D, E ANNA OSZYWA-CHABROS ${ }^{2, \boldsymbol{B}}$, JOANNA MALICKA², D, E, AGATA SMOLEŃ ${ }^{3, \mathrm{c}}$, JADWIGA DANILUK ${ }^{1,4}, \mathrm{~A}$, JERZY S. TARACH ${ }^{2, \text { A }}$

${ }^{1}$ Chair of Internal Medicine and Department of Internal Medicine in Nursing, Medical University of Lublin

2 Department of Endocrinology, Medical University of Lublin

${ }^{3}$ Chair and Department of Epidemiology and Clinical Research Methodology, Medical University of Lublin ${ }^{4}$ Department of Health of the Faculty of Health Sciences and Social Sciences of the Pope John Paul II National College in Biala Podlaska

A - Study Design, B - Data Collection, C - Statistical Analysis, D - Data Interpretation, E - Manuscript Preparation, $\mathbf{F}$ - Literature Search, $\mathbf{G}$ - Funds Collection

Summary Background. Understanding the principles of prophylaxis, and awareness of the importance of proper nutrition in maintaining wellbeing should be a part of every doctor-patient relationship.

Objectives. An evaluation of the sources of knowledge and access to information about healthy nutrition in primary care outpatient clinics.

Material and methods. The study comprised 222 subjects (150 women and 72 men) aged 18-87 years (median 47.5$)$. The study used a self-prepared questionnaire.

Results. $97.7 \%$ of the patients $(n=217)$ were aware of the impact of diet on health, of which only $9.9 \%(n=22)$ knew the rules of healthy nutrition well, $55.4 \%(n=123)$ had knowledge at a medium level, and $31.1 \%(n=69)$ at a low level. Dietary mistakes were more frequently reported by men $(p=0.001)$, and lack of time $(38.2 \% ; n=85)$ and knowledge $(29.3 \% ; n=65)$ were reported as the main reasons. The Internet $(64.9 \% ; n=144)$ is the main source of knowledge about healthy nutrition. It is used mainly by younger people $(78.9 \%<50$ years; $n=97$ vs. $47.5 \% \geq 50$ years; $n=47 ; p<0.001)$. People $\geq 50$ years prefer to talk with a doctor $(22.2 \% ; n=22 \mathrm{vs.} 4.9 \% ; n=6 ; p<0.001)$. Patients expect to get dietary education in their primary care outpatient clinic in the form of leaflets $(58.6 \% ; n=130)$, posters $(25.7 \% ; n=57)$, conversation with a doctor $(36.9 \% ; n=82)$, and consultation with a nutritionist $(33.3 \% ; n=74)$. Significantly more women want to get information directly from a doctor $(p=0.01)$.

Conclusions. The primary care outpatient clinic is an important source of information on healthy nutrition. Patients expect access to information in the form of leaflets and medical or dietary consultations conducted in a family doctor's practice. We should consider the implementation of educational programmes on the principles of healthy nutrition in primary care outpatient clinics.

Key words: prevention, nutrition, health promotion.

Fam Med Prim Care Rev 2016; 18(3): 230-234

\section{Background}

The importance of prophylaxis in the prevention of cardiovascular diseases, metabolic disorders and cancer is well known [1]. Applying the principles of a healthy lifestyle is an important element of prophylaxis and an expression of personal responsibility for one's own health at the same time. Stressing the principles of proper nutrition and their importance in maintaining health should be a part of every doctorpatient relationship. The primary care outpatient clinic, due to frequent contact with the patient, should be a place that promotes a healthy lifestyle.

\section{Objectives}

The aim of the study was to evaluate the sources of knowledge about the principles of healthy nutrition and the assessment of patients' expectations about dietary education in primary care outpatient clinics.

\section{Material and methods}

The study comprised 222 people (150 women and 72 men) ranging in age from 18 to 87 years (median 47.5, lower quartile 29 years, upper quartile 60 years) hospitalized in the Department of Endocrinology, treated at specialist outpatient clinics and the primary care outpatient clinic at the Independent Public Teaching Hospital No. 4 in Lublin. The characteristics of the study group are shown in Table 1. For statistical purposes the patients were divided into two age groups: under 50 years $(55.4 \% ; n=123)$ and aged 50 years and older $(44.6 \% ; n=99)$.

The study applied the technique of a diagnostic survey which used a research tool: a self-prepared questionnaire; its completion was anonymous and voluntary, and the selection of subjects was random. The questionnaire of the survey included five questions about demographic data and 14 questions concerning the existence and character of chronic diseases, opinions on the impact of diet on health, and selfassessment of the level of knowledge about the principles of 
nutrition. The surveyed patients were also asked about the availability of information on nutrition at their primary care outpatient clinic and expectations in this regard.

\begin{tabular}{|c|c|}
\hline Variable & \\
\hline Number of patients & $n=222$ \\
\hline Age $^{1}$ (years) & $47.5(18-87)$ \\
\hline $\begin{array}{l}\text { Gender } \\
\text { women } \\
\text { men }\end{array}$ & $\begin{array}{l}n=150(67.6 \%) \\
n=72(32.4 \%)\end{array}$ \\
\hline $\begin{array}{l}\text { Place of residence } \\
\text { village } \\
\text { town }<100000 \text { inhabitants } \\
\text { city }>100000 \text { inhabitants }\end{array}$ & $\begin{array}{l}n=66(29.7 \%) \\
n=62(27.9 \%) \\
n=94(42.4 \%)\end{array}$ \\
\hline $\begin{array}{l}\text { Marital status } \\
\text { married } \\
\text { divorced } \\
\text { single } \\
\text { widowed }\end{array}$ & $\begin{array}{l}n=67(52.3 \%) \\
n=0 \\
n=67(30.2 \%) \\
n=39(17.6 \%)\end{array}$ \\
\hline $\begin{array}{l}\text { Education } \\
\text { elementary } \\
\text { vocational } \\
\text { secondary } \\
\text { higher }\end{array}$ & $\begin{array}{l}n=21(9.4 \%) \\
n=27(12.2 \%) \\
n=88(39.7 \%) \\
n=86(38.7 \%)\end{array}$ \\
\hline
\end{tabular}

${ }^{1}$ Median (min and max range).

The results were statistically analyzed. In the nominal scale the values of the analyzed parameters were characterized by number and percentage, and in the quotient scale (due to the oblique distribution of age of the subjects evaluated using the Shapiro-Wilk test) using the median value, with the lower and upper quartile giving a range of variation. The Chi-square test was used to detect differences or dependencies, and a 5\% error of deduction was accepted. Statistical analyses were based on STATISTICA V. 10.0 StatSoft software, Poland.

\section{Results}

The analysis of compiled figures shows that $86.9 \%(n=$ 193) of the subjects declared the presence of chronic dis- eases. Their characteristics are shown in Figure 1. The vast majority of subjects $(97.7 \% ; n=217)$ admitted that they had awareness of the impact of diet on health, but only $9.9 \%$ ( $n=22$ ) knew the rules of proper nutrition at a good level, and $55.4 \%$ of the subjects $(n=123)$ declared a knowledge of these principles at a medium level. Another $31.1 \%$ of the surveyed individuals $(n=69)$ evaluated their knowledge about proper diet as low, and $3.6 \%$ of the patients $(n=8)$ did not know these rules at all. Better knowledge of the principles of nutrition was more often reported by women (at good and medium levels: $72.7 \%$ of women; $n=109$ vs. $50 \%$ of men; $n=36 ; p=0.002$ ) and younger people (including 'good' and 'medium' answers: $70.7 \%$ of people $<50$ years old; $n=86$ vs. $58.5 \%$ of patients $\geq 50$ years old; $n=58 ; p=0.07$ ). In addition, awareness of the principles of nutrition was higher among better educated subjects (respectively $71 \%(n=61)$ with higher education, $69.2 \%(n=61)$ with secondary education, $48.1 \%(n=13)$ with vocational education and $47.6 \%$ of patients $(n=10)$ with primary education $(p<0.001)$.

$97.7 \%$ of the subjects $(n=217)$ declared applying, to different degrees, the principles of healthy nutrition in everyday life. A detailed distribution of responses is presented in Figure 2. Men significantly more frequently did not obey the principles of proper nutrition (answers "no" and "rare" together; $51.4 \%$ men; $n=37$ vs. $26.7 \%$ women; $n=40 ; p=0.001$ ). The subjects sought the main cause of failure to comply with the above principles in the lack of time $(38.2 \% ; n=85)$ and knowledge in this field $(29.3 \% ; n=65)$. Women more often indicated the lack of knowledge as the main cause of failure to comply with the principles of healthy nutrition $(35.3 \% ; n=53 v s .16 .7 \%$; $n=12 ; p=0.0002$ ), while men were significantly more likely to admit that the cause was their own choice (respectively $23.6 \% ; n=17$ vs. $6 \% ; n=9 ; p<0.001$ ). The lack of time as the main cause of bad eating habits was more often indicated by men compared to women (44.4\%; $n=32$ vs. $35.3 \% ; n=53$; $p<0.001)$ and the younger surveyed subjects $(47.1 \%$ in the group $<50$ years old; $n=58$ vs. $27.3 \%$ in $\geq 50$ years old; $n=27 ; p<0.001$ ).

The sources of information about nutrition for the subjects are presented in Figure 3. In the study group, the Internet was the main source of knowledge about healthy eating $(64.9 \% ; n=144)$. However, this source of information was more common among relatively younger subjects $(78.9 \%$ of the subjects $<50$ years old; $n=97$ vs. $47.5 \%$ of the group

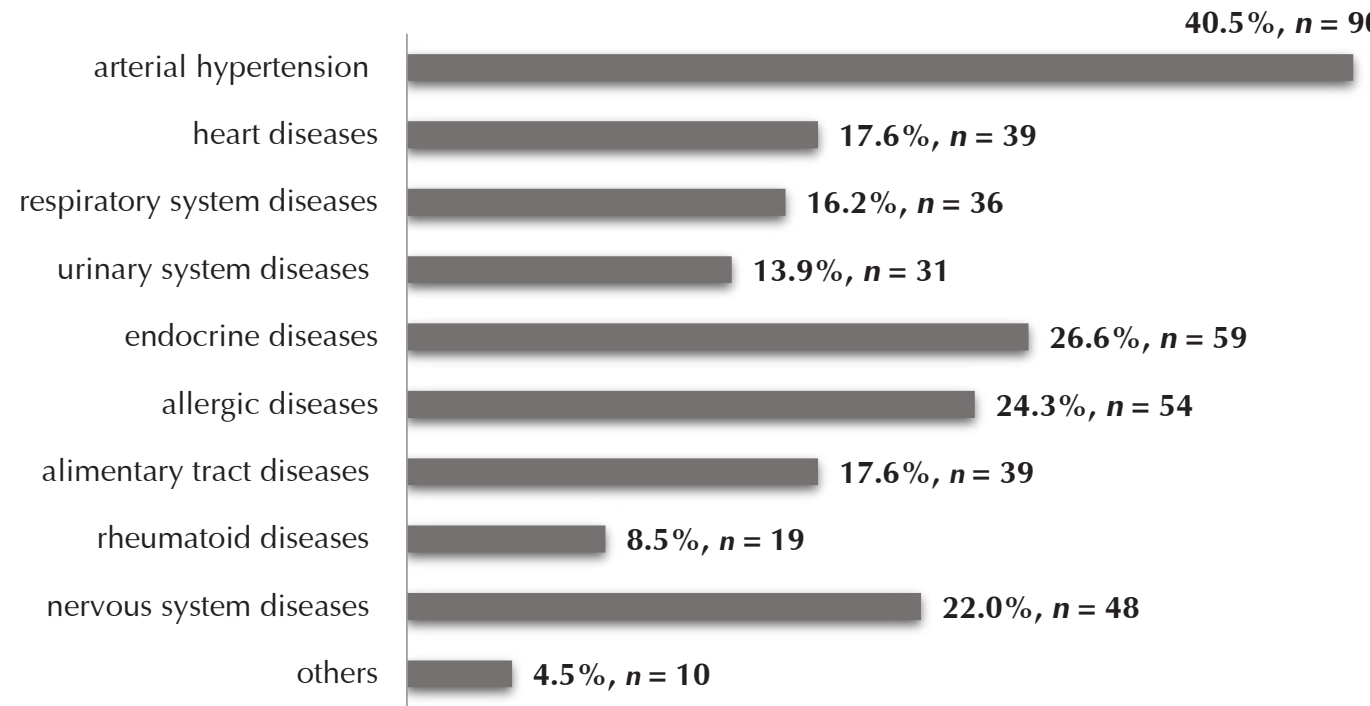

Figure 1. The incidence of chronic diseases in the study group of patients ${ }^{1}$ 


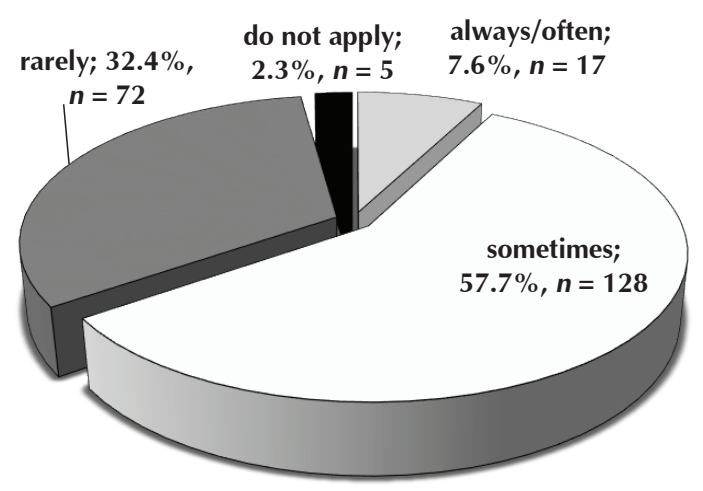

Figure 2. Self-assessment of the subjects in the application of the principles of healthy nutrition

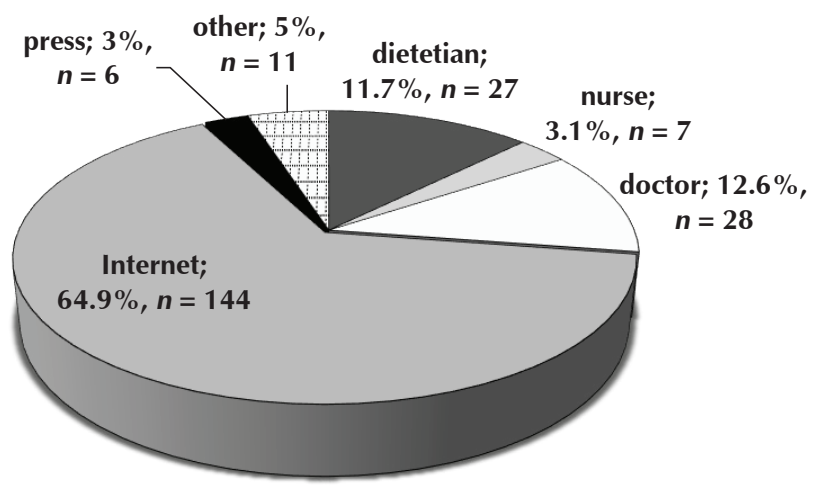

Figure 3. How do you usually obtain information about the principles of healthy eating?
Yes, in the form of leaflets
Yes, in the form of posters

Yes, the information is provided by a doctor

Yes, the information is provided by a nurse

Yes, the information is provided by a nutritionist

Yes, in other forms

No

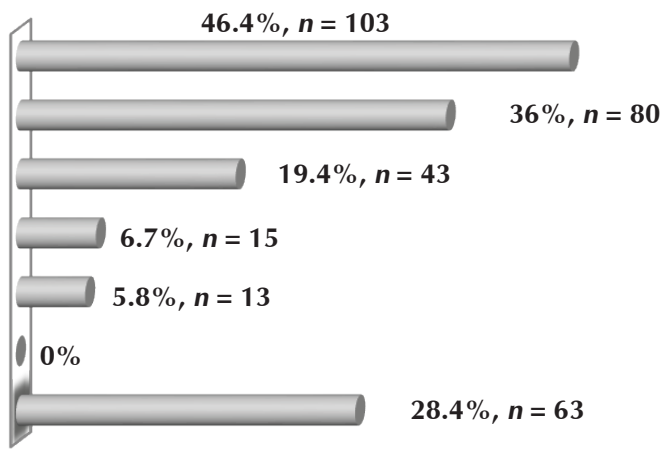

Figure 4. Does your primary care outpatient clinic provide information concerning the principles of healthy eating?'

${ }^{1}$ Percentages do not add up to $100 \%$ due to the fact that one patient could choose several responses.

Yes, in the form of leaflets
Yes, in the form of posters

Yes, the information should be provided by a doctor

Yes, the information should be provided by a nurse

Yes, the information should be provided by a nutritionist

Yes, in other forms

No

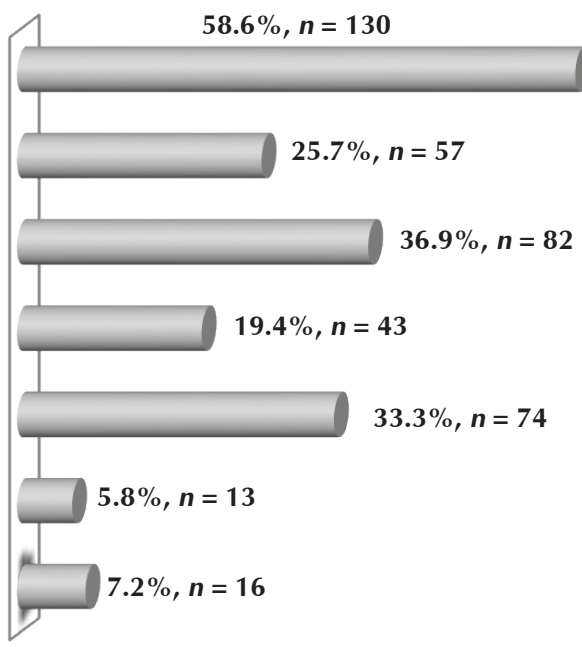

Figure 5. Do you think it is desirable to have information on nutrition principles available at your primary care outpatient clinic?

${ }^{1}$ Percentages do not add up to $100 \%$ due to the fact that one patient could choose several responses.

$\geq 50$ years old; $n=47 ; p<0.001)$. People $\geq 50$ years of age prefer to talk with a doctor $(22.2 \% ; n=22$ vs. $4.9 \% ; n=6$; $p<0.001$ ).

The subjects were asked whether their primary care outpatient clinic provides information about the principles of healthy nutrition, and in what form. The results of the study are shown in Figure 4. The largest number of patients declared that the information is presented in the form of leaflets or posters. This form of communication was significantly more often noticed by women ( $52 \%$ women; $n=78$ vs. $34.7 \%$ of men; $n=25 ; p=0.01$ ) and those relatively older $(62.6 \%$ of the study group $\geq 50$ years old; $n=62 \mathrm{vs} .33 .3 \%$ of subjects $<50$ years old; $n=41 ; p<0.001)$. Also, women more often sought medical advice on nutrition $(22.7 \%$; $n=34$ vs. $12.5 \% ; n=9 ; p=0.07)$, as well as individuals $\geq 50$ years of age $(26.3 \% ; n=26$ vs. $13.8 \% ; n=17 ; p<0.001)$. The fact that nearly $1 / 4$ of the study population $(28.4 \%$; $n=63$ ) reported that their primary care outpatient clinic did not provide any information about healthy eating is alarming, which was predominant in the group of relatively younger people ( $35.8 \%$ of subjects $<50$ years old; $n=44 \mathrm{vs}$. $19.2 \%$ of patients $\geq 50$ years old; $n=19 ; p=0.006$ ).

The subjects were asked to identify their expectations of primary care outpatient clinics in terms of dietary education. The results are shown in Figure 5. Most of them, 58.6\% of the subjects ( $n=130$ ), expect to have access to information leaflets. Significantly more women want to get information on this directly from a doctor $(42.7 \%$ women; $n=64 \mathrm{vs}$. 
$25 \%$ of men; $n=18 ; p=0.01)$. City dwellers anticipate to have the possibility of consulting with a nutritionist $(35.2 \%$; $n=55$ vs. 28.8\%; $n=19 ; p=0.02$ ). Patients treated for chronic diseases have higher expectations of medical advice on nutrition in the primary care outpatient clinic $(56.5 \%$; $n=109$ vs. $34.4 \% ; n=10 ; p<0.001)$. Only $7.2 \%$ of the subjects $(n=16)$ do not expect any action in this regard from primary care outpatient clinics.

\section{Discussion}

The results confirm that the vast majority of patients are aware of the impact of diet on health. The mass media, along with the medical community, publicize warnings about obesity and its consequences, trying to raise more awareness in the knowledge of the products consumed [2, 3]. According to the literature, an increase of nutritional awareness achieved though the provided information is usually accompanied by improvements in health behaviour [4, 5], though not all sources confirm the direct relationship [6]. The increased effectiveness of dietary advice is undoubtedly connected with the ability to transfer information, as well as a positive and long-lasting relationship with the patient [3, 7], which is undoubtedly an asset to the family doctor.

In the study group of patients, the vast majority of the subjects reported chronic diseases, and this group in particular reported the need for access to nutritional counselling in primary care outpatient clinics. The awareness of the role of nutrition in the etiology of diseases, particularly cardiovascular and metabolic diseases, is encouraging in this group of patients, but the implementation of recommendations does not always go hand in hand with awareness. Because of the nature of the disease, the transmission of information on proper nutrition during frequent visits to a primary care outpatient clinic would increase the chances of success. Advice provided by a doctor, nurse or nutritionist would be particularly valuable for older people, for whom the acquisition of information in an alternative way (press, Internet) is still a barrier. The effectiveness of nutrition education in patients with cardiovascular disease, carried out in an outpatient setting, including primary care outpatient clinics, has been proven by other authors $[5,8,9]$. There have been positive changes in the application of the principles of healthy nutrition, the frequency of exercise, and the quality of life [8]. Other researchers also recognize the role of the family doctor in promoting proper diet $[3,10,11]$.

Health education, including dietary information, is more likely to be implemented in the hospital, because it is carried out with the participation of educators and dietitians trained in this area, and with an extensive amount of time $[12,13]$. However, everyone knows that prevention is more effective and economically justified, and education conducted in an outpatient setting would give many a chance to avoid hospitalization. Because of the most frequent contact with the patient, the family doctor often becomes the first resort to which the patient reports. It is obvious that there is no time for education during a regular visit, because meeting with the patient mainly focuses on solving the current problem and treatment, and rarely on prevention. According Buczkowski, nearly $40 \%$ of patients had never talked with their family doctor about proper nutrition [3]. Therefore, the general practitioner ought to mention an increase of the availability of printed material and the possibility of periodic training with a nutritionist, which, as confirmed by our results, definitely has its audience. Undoubtedly, however, primary care outpatient clinics should not be left alone in designing, funding and implementing the programme. It should be carried out on a national scale, where primary care patients would benefit. The problem of financing educational materials outside the primary care funds remains. The solution could be nationwide educational programmes on healthy eating financed from budgetary sources and NGOs (non-govermental organizations). In addition to media advertising, they should be targeted at the direct contact with the patient, e.g. in primary care outpatient clinics. The implementation of the programme could be performed without the participation of an educator, dietitian or doctor, and take the form of leaflets and posters. Another form could be periodic meetings with a promoter, carried out in units wanting to join the programme, and with the possibility of housing in this area. The popularization of the principles of nutrition in line with the new nutrition pyramid [14] would be an excellent rationale to take this type of educational activities, and the potential of primary care in a wide contact with the patient is not to be missed.

This is an object study, which is meant to draw the reader's attention to the problem of how to feed our patients, and the potential role of primary care outpatient clinics in improving health behaviours. The accurate assessment of this phenomenon requires deeper research, which is a challenge for authors in the future.

\section{Conclusions}

The primary care outpatient clinic is an important source of information in the field of proper nutrition. Patients expect access to informational material concerning nutritional conduct, mainly in the form of leaflets and medical and dietary advice, available in primary care outpatient clinics. We should consider the implementation of educational programmes on healthy eating principles in primary care outpatient clinics.

Source of funding: This work was funded by the authors' resources. Conflict of interest: The authors declare no conflict of interests.

\section{References}

1. Sobolewska A, Sztanke M, Boguszewska-Czubara A, et al. Influence of physical activity and nutritional habits on occurence of metabolic diseases. Zdr Publ 2007; 117(4): 419-424.

2. Babińska Z, Bandosz P, Trzeciak B, et al. Świadomość posiadania nadwagi pierwszym krokiem w zapobieganiu otyłości i jej powikłaniom. Fam Med Prim Care Rev 2006; 8(3): 572-574.

3. Buczkowski K, Ignaczak E, Dachter-Frąckiewicz M, et al. Próba oceny stylu życia pacjentów lekarzy rodzinnych. Fam Med Prim Care Rev 2005; 7(3): 613-617.

4. Ferrini F, Edelstein S, Barret-Connor E. The association between health beliefs and health behavior change in older adults. Prev Med 1994; 23(1): 1-5.

5. Amar S, Tiben N, Karabi K, et al. The efficacy of doctor-patient appointment a primary care setting dedicated to preventive medicine. Harefuah 2001; 140(8): 689-693.

6. Szewczyński J, Ostrowska A. Assesment of dietary habits of Medical Academy students. Part III. Results of quantitive assessment. Żyw Człow 1990; 17(2): 103-111. 
7. Jeżewska-Zychowicz M. Zastosowanie procesu komunikowania interpersonalnego w poradnictwie dietetycznym. Żyw Człow 2006; 33(1): 84-90.

8. Michoń J, Uchmanowicz I, Lomper K, et al. Wpływ edukacji zdrowotnej na jakość życia chorych z nadciśnieniem tętniczym. Probl Pielęg 2014; 22(3): 319-326.

9. Wiesemann A, Metz J, Nuessel E, et al. Four years of practice-based and exercise supported behavioural medine in one community of the German CINDI AREA. Countrywide Integrated Non-Communicable Diseases Intervention. Int J Sports Med 1997; 18(4): 308-315.

10. Zatoński W. Wstęp. In: Mierzecki A, Godycki-Ćwirko M, eds. Zagadnienia profilaktyki i promocji zdrowia. Łódź: Atkis Sp. z o.o.; 2000: 6-7.

11. Rogowska D. Rola dietetyka w profilaktyce chorób dietozależnych. Pol Med Rodz 2000; 2(3): 246-247.

12. Ciok J, Kamińska M. Ocena skuteczności programu edukacji żywieniowej pacjentów szpitalnych jako metody prewencji wtórnej chorób układu krążenia. Prom Zdr 2001; 8(20): 111-124.

13. Ciok J, Kamińska M, Dzieniszewski J. Przegląd metod prowadzenia edukacji żywieniowej wśród pacjentów szpitalnych. Pol Merkuriusz Lek 1999; 7(41): 236-241.

14. Instytut Żywności i Żywienia. Zasady prawidłowego żywienia [cited 25.05.2016]. Avaible from URL: http://www.izz.waw.pl/ $\mathrm{pl} /$ zasady-prawidowego-żywienia.

Address for correspondence:

Marta Dudzińska, MD, PhD

Katedra Interny z Zakładem Pielęgniarstwa Internistycznego UM

ul. Jaczewskiego 8

20-954 Lublin

Polska

Tel.: +48 81 742-58-25

E-mail: m.dudzinska1@o2.pl

Received: 01.04.2016

Revised: 19.05.2016

Accepted: 27.05.2016 